\title{
OVERVIEW OF WELLNESS METHODS FOR PEOPLE PRACTICING SPORTS
}

D01:10.36740/WLek202102133

\author{
Justyna Laskowska, Olga Hadław-Klimaszewska, Agnieszka Jankowska, Adam Zdziechowski, Marta Woldańska-Okońska \\ DEPARTAMENT OF REHABILITATION AND PHYSICAL MEDICINE, MEDICAL UNIVERSITY OF LODZ, LODZ, POLAND
}

\begin{abstract}
The term "wellness" embraces a wide spectrum of methods that impact the human body by restoring its capabilities and functions, which were previously depleted as a result of increased physical and mental activities such, i.e. sport. Judging by the number of amateur, semi-professional, and professional sporting events at local and national levels, societies consider sports a major part of their everyday lives. A growing percentage of the population is exposing their bodies to various strains, which may result in fatigue, overtraining and injuries, and so the market demand for recovery-related services is on the rise. Therefore, this paper is an overview of the most important and the latest wellness systems and methods applied in today's sport. They divide into three areas: pedagogical, psychological and medical-biological. Among the most popular treatments are: light radiation with infrared rays, cryotherapy, electrotherapy, magnetotherapy, ultrasound and laser therapy, as well as a sauna, paraffin compress, mud compress and brine baths. In a broader context, the paper also acknowledges the growing demand for better body recovery methods and the latest developments in the field of sport physiotherapy.
\end{abstract}

KEY WORDS: wellness, recovery, sport, physical therapy

Wiad Lek. 2021;74(2):355-361

\section{INTRODUCTION}

The term 'biological regeneration' is often understood in a rather general way and often used interchangeably with e.g. the word 'SPA' or 'wellness'. Contrary to its common understanding, specialist literature specifies the term as follows:

"This term is understood as a number of effects (...) on the human body aimed at counteracting overstrain and restoring full physical fitness and mental motivation which have been deteriorated due to exhausting physical and mental work, local fatigue of mainly the musculoskeletal system, convalescence, etc." [1].

In a slightly broader sense, biological regeneration is applied in three areas:

"A group of psychological, educational and biological effects, the aim of which is to activate the relaxation process, which is closely related to the protection and enhancement of health" [2].

\section{AIM}

This paper presents an overview of established and novice therapies of biological regeneration in the context of growing popularity of various forms of physical exercise.

\section{REVIEW AND DISCUSSION}

\section{HISTORY AND THE PRESENT}

Interestingly, restoring the body to its healthy condition and functionality from previous intensive physical activity is not a modern invention. It originates in antiquity, where sport played an important role in life and culture of, for example, the Greeks. High physical fitness was perceived by the Greeks as a proof of human perfection and a way to live a vital, healthy life. It is certain that already in those days, wellness treatments were used to improve the body's efficiency and recovery, because apart from artists or philosophers, the players were also accompanied by physicians. Hippocrates himself watched training sessions to better understand the human body and to develop better dietary recommendations. Dissertations were written on training regimes, and Galen ( $2 \mathrm{nd} / 3$ rd century $\mathrm{AD}$ ) came to the conclusion that medics must train equally hard as athletes with whom they worked, in order to achieve excellence in their medical field [3].

\section{THE GROWING ROLE OF BIOLOGICAL REGENERATION}

Today, sport is not only a form of spending free time, relaxation, detachment from everyday life. Society is becoming increasingly aware and increasingly often experiences its beneficial effects on mental and physical health. It can already be noticed that both young and elderly people as well as entire families are often present at various events, health paths where they try to push the limits of their endurance. This in turn means that the percentage of people experiencing fatigue, overtraining and injuries will inevitably increase. As a consequence, there will be a growing demand on the market for effective regenerative treatments, and the effectiveness of 
such treatments rely on expert knowledge about applying biological regeneration therapies and specialized equipment. It can be safely assumed that the growing number of amateurs and semi-professionals will be aware that biological regeneration applied at various stages of training - not only in the case of fatigue or more serious injuries - prepares the body to achieve better physiological results. All of the above aspects mean that in the field of biological regeneration there is a growing demand for a) specialists who know how to apply such methods in the context of sport and b) for increasingly effective methods of body regeneration. Therefore, it is worth reviewing the most important systems and methods of biological regeneration as well as looking at the directions of development of this increasingly important field of medicine.

\section{SYSTEMS OF BIOLOGICAL REGENERATION}

Biological regeneration encompasses tools that can be divided into three areas: educational, psychological and medical-biological $[4,5]$.

1. Educational measures:

- creating training plans that are optimal in terms of the athlete's abilities

- proper planning of training cycles

- accounting for balance between exercise and rest in training

- including specialist training sessions aimed at providing the best conditions for physical and mental relaxation

- achieving motivation levels sufficient to mobilize and activate the mind and the body [5].

2. Psychological measures:

- developing conditions conducive to building good interpersonal relations, e.g. between a player and the team, coaches, doctors, etc.

- providing special forms of rest and relaxation which eliminate players' mental strain

- strengthening mental resilience with appropriate cooperation with the coach and psychologist [5].

3. Medical and biological measures:

- adapting dietary plans to the current needs of the athlete

- ensuring proper healthcare

- applying physical medicine treatments and spa therapies [5].

\section{AIMS OF WELLNESS}

Skilfully applied biological regeneration can increase the effectiveness of each training stage. In this regard, its tasks can be divided into essentially four elements:

1. Planning out post-exercise recovery at the stage of creating a training plan, which is aimed at more efficiently remedy functional disorders $[1,5]$.

2. Recovery optimization: selection of appropriate therapies which accelerate the regenerative activities of an athlete's body to restore them to their current needs

3. Prevention: proper training and training methodology and physical activity as well as eliminating the effects of effort, among others, the production of defence and adaptation mechanisms.

4. Completing healing processes of suffered injuries that often lead to long absence from sports activity. The most common are bruises, skin abrasions, and damage to the capsulo-ligament apparatus $[1,5]$.

Biological regeneration, due to its wide application possibilities, is used and should be used in every training phase and selected according to the type of physical activity. The most common treatments of biological regeneration include: infrared irradiation, hydrotherapy, cryotherapy, heat therapy, electrotherapy, magnetic therapy, ultrasound therapy, massages and balneotherapy.

\section{HYDROTHERAPY}

It is probably the most often used type of physical therapies applied in post-exercise recovery process. Water-based treatments are in essence mechanical stimulation of the body through various levels of pressure and a broad range of temperatures as well as a beneficial effect of water resistance and buoyancy. The most important effects of hydrotherapy are local and systemic reactions of the body to heating, cooling, local mechanical stimulation (e.g. showers, hydromassage) and reaction to immersion in water due to water's relieving and resisting effects. Overall, the goals of the various hydrotherapy approaches can be summarized as striving to reduce chronic pain and inflammation, muscle tension disorders as well as improving coordination and mobility [6-10].

\section{CRYOTHERAPY}

The beneficial effect of systemic cryotherapy comes from reactions of a body subjected to very low temperatures of -100 oC to even -160 oC for about 2-3 minutes. Systemic treatments take place in specially designed rooms, e.g. cryo-chambers or cryo-saunas where the room is cooled with liquid nitrogen. Local treatments, on the other hand, use e.g. ice, cold water, frozen gels, compresses or airflow of liquefied $\mathrm{CO}_{2}$. The goal is to cause physiological stress, in which first the peripheral blood vessels and muscles contract and the blood flow and metabolism slow down. Then the body in a defensive reaction rapidly dilates the vessels increasing blood flow. As a result, the amount of nutrients, oxygen and anti-inflammatory mediators supplied to the cells increases. These reactions make cryotherapy an excellent solution for relieving pain, swelling and inflammation states, stimulating regeneration of damaged tissues, relaxing muscles and increasing the range of motion. It has a positive effect on metabolism and stimulates the nervous and immune systems. It often clearly improves also the well-being of active people who underwent surgical operation $[6,7,9-14]$.

Indications for cryotherapy are e.g.:

- rheumatological and degenerative diseases,

- post-traumatic conditions, 
- lesions resulting from overstraining the musculoskeletal system,

- in biological regeneration, e.g. in the case of athletes, with physically and mentally fatigued people and in myofascial pain syndromes $[6,7,9,15]$.

\section{HEAT-BASED THERAPIES}

The sources of heat in biological regeneration can be warm water or heated dry or humid air. Therapeutic treatments can be used locally or systemically. The body's primary reaction to the heat is a the reaction of the blood vessels. As a result of the heat, the blood vessels of the skin and those that supply blood to the kidneys, spleen and brain expand and, in accordance with the Dastre-Morat law, large vessels of the chest and abdomen react antagonistically and constrict. An opposite pattern occurs when applying cold therapies. Constricting vessels inside the body lead to reduced blood circulation and reduced oxygen supply to deeper tissues, which triggers the desired adaptation - the number of red blood cells increases, the overall oxygen management improves and the number of capillaries in internal organs and muscles increases. During systemic treatments (e.g. bathhouse, sauna), the body gets overheated, which entails a number of effects: profuse sweating affects the water and mineral balance of the body, metabolism increases (body temperature increase by $1^{\circ} \mathrm{C}=$ rise in metabolism by approx. $3.6 \%$, which for example in the case of sauna means a rise by $11 \%$ ), heartbeat and breathing pace accelerate. In the context of sport, one of the most beneficial effects of overheating is reduced muscle tension. It has also been proven that, e.g. during sauna treatments and up to a dozen or so hours after treatment, the pituitary and adrenal glands secrete hormones. The adrenal glands increase cortisol production, which, among others, increases exercise capacity $[6-8,10,12]$. For local treatments, in order to achieve a reaction some of the equipment used are e.g. electric cushions, thermophores or heating lamps (e.g. sollux). Blood and lymphatic vessels expand when exposed to heat. Such increased blood flow has beneficial effect e.g. in inflammation treatment. Heat relieves pain and reduces muscle tone of skeletal and smooth muscles. Therapies using sollux lamps are used in chronic and subacute inflammation of joints and periarticular tissues, post-injury pathologies of the musculoskeletal system, myalgia, and in tendon, ligament and muscle disorders due to biomechanical overload. It is also recommended to use infrared radiation to warm the skin and any cold areas of the patient's body before massage, kinesitherapy and stimulation with electricity $[7,8]$.

Ultrasounds (sound therapy also known as sonotherapy, phonotherapy, ultrasound therapy, ultrafonotherapy)

Ultrasounds are acoustic waves inaudible to the human ear, i.e. above $20 \mathrm{kHz}$, and therapies use a range of approx. $800-2400 \mathrm{kHz}$. Ultrasound therapy is one of the most widespread therapies all around the world, just as in Poland. Interestingly, it is also one of the best-studied methods of physical therapy, both in terms of the physical phenomenon of ultrasound and its effects and effectiveness. Unlike the methods of physical therapy described so far, exposure to sounds is primarily executed using local procedures (primary ones), which indirectly affect other parts or the entire system, and in such case their effect is described as secondary. Local action on tissues is a complex process which consists of three main aspects:

a. Physicochemical effect: physicochemical changes induced by ultrasound depend mainly on the intensity of the wave, and then on other parameters such as the duration of the procedure or the type of tissue. Significant effects include acceleration of protein breakdown, transformation from gel to sol, and increased electrical conductivity. Most of the chemical reactions that result from sound treatment are oxidation.

b. Mechanical action: When the acoustic wave propagates, it causes the particles of the medium (e.g. air, water) to vibrate, therefore an acoustic wave is also a mechanical wave, therefore the way sound waves affect gases, liquids and solids is mechanical, physical. In this context, the effect of ultrasound on tissues is referred to as micro-massage, and its effect on cells is e.g. a change in cell volume by $0.2 \%$, which is a significant change.

Summarizing the two points above, the athermal effect of ultrasound stimulates the flow of intra- and extracellular fluids as a result of changing pressure and increased permeability of cell membranes. As a result, there is an anti-inflammatory effect and repair processes accelerate.

c. Thermal action: One of the effects of mechanical action is generation of thermal energy, which depends on the parameters of ultrasound used, exposure time and the level of wave absorption by a given tissue. The thermal effect is strongest in the border area of heterogeneous tissue structures, e.g. bone and muscle tissue. Next, the most susceptible to the overheating effect are the nervous tissue, slightly less muscles, and the least susceptible is the adipose tissue. In practice, this means that the therapy is suitable for tissues with high collagen content, such as tendons, ligaments, joint capsules heating increases their elasticity without reducing their strength $[7,11,12,16,17]$.

\section{SHOCKWAVE THERAPY}

One of the varieties of ultrasound therapy is the so-called Shockwave therapy. This is a relatively new method that was first used in the treatment of kidney stones, where it was found that in addition to crushing the stones, a side effect is relieving ailments related to the musculoskeletal system. The method is highly effective; it sometimes postpones and even prevents operations after injuries or degenerations of the locomotor system $[11,18,19]$. Due to its very fast and measurable effects, the method has a special place in sport and is primarily used for treating pain and inflammation, and one of its first applications in biological regeneration during major sporting events was the Olympic Games in Atlanta in 1996 and at the football World Cup in France two years later. The procedure is a series of rapid increases 
in pressure: from 1500 to 3000 wave shocks up to 21 times per second. The medium of propagation of such waves is most often water, and to facilitate transmission deep into the tissues are used for example so-called ultrasound gels are used, for example. It is a very precise method as it gets applied onto a selected area and affects only or mainly pathological tissues. The impact of the wave is achieved even up to 12 centimetres deep into the tissue. The most common conditions treated with the shockwave are damage to the tendons and joint capsules, tendon attachment, patella pain, post-traumatic pain syndromes, myalgia, achilles injuries, shoulder and wrist injuries, patellar tendonitis and many others $[11,16,18-20]$.

\section{MAGNETIC THERAPY}

The therapeutic factor in magnetic therapy is variable magnetic field for which a specific frequency and magnetic induction, i.e. field strength, are selected. One of its applications is treating muscle and tendon injuries and post-exercise muscle fatigue, because magnetic field penetrates all body structures, improves oxygenation and blood supply. In addition, the osteogenic effect accelerates broken bone healing process. Magnetic therapy is a non-thermal method of physical therapy, and due to the fact that magnetic field is able to penetrate most substances, it is thus effective also when the subject wears a cast. The shape of generated magnetic field pulses varies for different applications of the method, e.g. triangular pulses are used for regenerating articular cartilage, tendons and ligaments, and sinusoidal pulses are used for nerves and muscles. Frequency (between 1 and approx. $80 \mathrm{~Hz}$ ) and the strength (between 0.5 and $10 \mathrm{mT}$ ) of the magnetic field are set up according to the condition, and lower values are applied for acute conditions and the highest for chronic conditions $[21,22]$.

\section{MAGNETIC STIMULATION THERAPY}

It is a form of therapy similar to magnetic therapy, but more modern and based on patented solutions. Magnetic stimulation therapy, unlike the magnetic therapy, uses a much lower induction (strength) and higher field frequency, which reaches even $3000 \mathrm{~Hz}$ (compared to a maximum of $100 \mathrm{~Hz}$ in magnetic therapy). The second significant difference is the shape of the magnetic field signal, which is described as sawtooth in the case of magnetic stimulation, while in magnetic therapy it takes different geometrical shapes [7, 8, 21, 22]. Magnetic stimulation relaxes smooth muscles in the walls of blood vessels, has an analgesic effect, accelerates regenerative processes, wound healing, stimulates bone formation, increases bone mineralization while inhibiting demineralisation processes and has an anti-inflammatory effect when stimulating the production of $\mathrm{E}$ and c-AMP prostaglandin. It is an increasingly popular form of biological regeneration, which may be even applied at home due to the increasingly popular magnetic devices (Viofor JPS System - one of the certified -CE- devices in magnetic stimulation therapy) as they show high rates of safety in application [21-24]. Therapy with the Viofor JPS system consists in affecting the body with a slowly changing magnetic field, which leads to changes in the body that support biological regeneration processes. As a consequence, mechanisms are launched in the body which clearly facilitate restoring homeostasis. This therapy uses a pulsed magnetic field of very low frequencies. The Viofor system, thanks to its appropriate dimensions, can be used in all conditions: at home, while travelling, before and after doing sports. Treating with magnetic stimulation can be carried out at any stage of the training cycle, even during breaks, and the best results are achieved by using magnetic stimulation after training (e.g. oxygen debt decreases, blood saturation improves, and muscle tone decreases). It is recommended to use the Viofor system in the following cases:

- pain,

- swelling,

- injuries of the soft tissue,

- injuries of joints and hard tissues,

- inflammatory conditions,

- neurosis, mood disorders,

- preventive sedative effect, aimed at counteracting stress of everyday life,

- stress, especially after prolonged mental tension (which is part of competing in sports),

- attention deficit disorders

- improves oxygenation of the body - better utilization of oxygen [21-24].

\section{ELECTROTHERAPY}

The aim of electrotherapy is to reduce pain and improve blood supply to stimulated tissues. It accelerates resorption of intra-articular oedema and effusions [12]. These treatments are performed with the use of direct or alternating current of varying frequency. Treatments based on the use of direct current are galvanization and ionithermie. In galvanization, depending on different electrode positioning, different therapeutic effects may be achieved which cause muscle relaxation (anodic electrode) or their stimulation (cathodic electrode) $[7,11,12,17]$. The flow of direct current through the tissues is accompanied by electrochemical, electrokinetic and electrothermal phenomena that increase the blood supply to the body stimulated with electricity as well as the threshold of nerve excitability and reduce their conductivity. Galvanic current increases absorption of hematomas, effusions and oedema due to increased vascular permeability, which is a result of secreting histamine. It improves blood circulation by having a beneficial nutritional effect on tissues, has anti-inflammatory and analgesic properties (the 'control gate' mechanism), and also accelerates regenerative processes, which allows faster wound healing [12]. Galvanization is used, among others, in pain syndromes associated with neuritis, flaccid paralysis, bone union disorders, post-traumatic conditions, muscle overstrain and abnormalities in the functioning of peripheral 
circulation [7]. Another treatment that uses direct current is iontophoresis, in which drugs dissociating into ions are introduced directly into the tissues. Characteristic for this treatment is that the healing factor are ions introduced into the body, and not the current itself. That is why it is so important to choose the right drug in a given disease entity $[6,7,12,25]$. The main goals to achieve in iontophoresis treatments are: analgesic and anti-inflammatory effects, improve blood flow, stimulate fluid resorption, change tissue structure, prevent the formation of adhesions and contractures, and stimulate tissue regeneration [26]. The next group are treatments using alternating currents.

Diadynamic currents arise as a result of rectifying sinusoidal alternating current with a frequency of 50 and 100 $\mathrm{Hz}$. The pulse duration is $10 \mathrm{~ms}$ and is equal to the pause time $[7,11]$. Diadynamic currents use sinusoidal pulses superimposed on direct current, in various combinations, depending on the required action, due to which they have analgesic and vasomotor properties, and also increase the excitability of the neuromuscular system. Beneficial results of diadynamic currents are used in such cases such as fatigue inflammations, tendon and muscle tears, in contusions, scar fractures and uncomplicated sprains. Whereas in combination with massage, balneotherapy and kinesiotherapy, they are applied to conditions after sprains and subluxations, in muscle atrophy and ankylosis resulting from inactivity of the joint, e.g. after long immobilization with a plaster cast $[5,7,12,20]$. The Träbert current, also called stimulus massage, is a unipolar, pulse, rectangular, low-frequency $(143 \mathrm{~Hz})$ current. The pulse duration is 2 $\mathrm{ms}$, and the break time is $5 \mathrm{~ms}$. These currents reduce the activity of the sympathetic nervous system, which causes muscle relaxation. Their use is recommended, among others, in pain syndromes, increased muscle tension, atrophies, in post-traumatic conditions, in Sudeck's syndrome and hyperalgesia [27-29]. Interferential currents are medium frequency currents $(1,000-10,000 \mathrm{~Hz})$, and their advantage is that they affect the inside of treated tissues and not the tissues directly under the electrodes. These currents are often used in cases of people who actively play sports, most often $90-100 \mathrm{~Hz}$ frequencies are applied due to their analgesic properties and relieving stress in the sympathetic nervous system. These currents are made as a result of overlapping two sinusoidal currents [27, 29].

\section{MASSAGE}

The most common physiotherapeutic regeneration treatment among athletes is a classic dry massage. The massage uses all known techniques such as stroking, kneading or rubbing [5]. The aim of sports massage is to prepare for extreme physical activity as fast as possible, achieve maximum results and remove considerable body fatigue after exercise. Massage has a very strong effect on the nervous system, especially on its neuromuscular part, improves tissue trophism, affects the circulatory system, relaxes the body and mind, improves sleep quality, removes muscle and joint pain and accelerates the excretion of metabolic products (body waste). In competitive sports, various types of massage are used such as training massage, massage applied before the competition, pre-workout massage, post-workout massage and support massage. Thus, the classic sports massage has a warming, regenerating and healing functions. In biological regeneration, water massage (underwater and whirlpool), isometric massage and pressure massage are also used $[5,8]$. Underwater massage should be used immediately after participating in sports competitions or hard training in water in the temperature range of $32-33^{\circ} \mathrm{C}$, and treatment time should be 10 minutes. Whirlpool massage - it is a vibration massage, it utilizes mechanical and thermal stimuli in a water environment, which lead to muscle relaxation, reduce pain and improve blood circulation. Pressure massage is performed using specialized devices such as special legs, belts and cuffs. Limbs are placed inside them, which are alternately affected by elevated and lowered atmospheric pressure. The biggest advantages of this method are very good stimulation of blood circulation and increase of muscle strength, and the fact that metabolic products are removed from the muscles. Stimulated blood circulation gives the desired feeling of lightness in the limbs subjected to massage, which is especially appreciated by runners. Pressure massage treatments are a great complement to a warm-up or end of training. Due to its high efficiency in improving strength and increasing muscle mass, pressure massage is an important supplement to training $[5,7-9]$

\section{INDIBA ${ }^{\circledR}$ ACTIVE IN SPORTS MEDICINE}

It is one of the state-of-the-art methods currently in use in physical therapy. It has been developed by Spanish specialists, and its effectiveness in sports, rehabilitation and aesthetic medicine has been thoroughly documented. The core of the method is a patented device which consists of two special electrodes that deliver thermal and non-thermal current to tissues and cells during short, maximum 15-minute sessions. This method uses the high frequency current of $448 \mathrm{kHz}$, which triggers a number of changes in tissues (it changes the permeability of the cell membrane, increases metabolism and oxygen demand). A big advantage of this therapy is the fact that when combined with manual therapy it can affect soft, cartilage and bone tissues. The main goals of the therapy are faster tissue reconstruction, lowering the pain threshold and reducing inflammation. The Indiba Activ method causes reactions in the body at the cellular level and forces it to create new, healthy cells, thanks to which tissue regeneration takes place faster. This results in reduced pain, it significantly reduces inflammation, and thus reduces the duration of treatment. Even tissues affected by chronic inflammation (a cause of many chronic conditions) are stimulated. Affecting the three types of tissues, referred to above, occurs by using two systems in two separate electrodes, which is the basis of the device's operation:

- resistive electrode - affects bone tissue, tendons and ligaments 
- condensation electrode - affects soft tissues, mainly muscles, and connective tissue

In light of the above benefits, the Indiba ${ }^{\circ}$ Activ method is successfully used in sports due to:

- reduction of pain

- reduced susceptibility to injuries

- faster recovery after exercise

- better physical preparation [30].

The method is used by Europe's top football clubs such as FC Barcelona, Liverpool FC, and also there is research collaboration with prestigious medical centres such as: Hospital Ramón y Cajal in Madrid, CIMA and QUIRON Hospitals in Barcelona, Santa Cruz and Sant Pau Hospitals in Barcelona, University Clinic in Valencia, CONI Medicine, Research and Sport Institute in Rome and Gaetano Pini Institute in Milan.

\section{BALNEOTHERAPY}

Balneology is a field of medicine that uses natural healing resources such as mineral water, medicinal gases, peloids and favourable climatic conditions. Currently, it is noticeable that balneotherapy is applied increasingly often in sports medicine and biological regeneration, especially in the prevention and treatment of injuries of athletes from various disciplines. Spa treatment increases the intensity of adaptive mechanisms, activates the body's functional reserves, their action is directed at the entire system, and therapeutic results after application last longer and are more permanent. Balneotherapy treatments are based on the properties of: medicinal materials, weather conditions, optimal living and relaxation conditions, and physical therapy equipment, which is an important addition to athletes' recovery processes [31-33]. In countries where sports culture is significantly developed and a large number of medals during sports competitions (World Championships, Olympics) are won, such as e.g. USA or Germany, there are a lot of rehabilitation centres for sports people, which were established many years ago. Currently, the same is true for Poland, where facilities dedicated to athletes are built with a wide range of balneo-treatments for biological regeneration, and which are gaining recognition and popularity.

\section{CONCLUSIONS}

The popularity of sport is undeniably growing and is expressed in the increasingly accessible infrastructure, numerous blogs and social media channels devoted to training, or even increasingly dense network of gyms, clubs and mass sports events. Together with the increasing number of people who train, the demand for effective biological regeneration naturally rises, hence this article provides an overview of the most important therapies in the context of regenerating the body after physical exercise. Bodies of people actively practicing sports experience various levels of strain, fatigue, overtraining, sometimes injuries, and the specificity of such conditions varies in every sports discipline. In addition, bio- logical regeneration methods are used as a prophylaxis and a way to increase the body's capabilities - it is more than just post-workout recovery, resting and relaxation. All this makes it necessary to know a wide range of therapeutic treatments and, equally important, to have an in-depth knowledge about individual therapies, because each procedure may be applied with various intensities and exposure times. In addition, one of the factors determining the selection of the right treatment at a given moment will be the need for mental recovery of the athlete. What is significant is that the variety of methods available allows avoiding falling into routine in conducting wellness.

Certainly, further research is needed to better understand the processes occurring in a body that undergoes physical therapy, to improve the effectiveness of existing methods, and to seek new therapies.

\section{REFERENCES}

1. Gieremek K, Dec L. Zmęczenie i regeneracja sił. Odnowa biologiczna. Bielsko-Biała: Has-Med, 2007.

2. Fenczyn J, Kasperczyk T. Podręcznik Odnowy psychosomatycznej. Państwowy Zakład Wydawnictw Lekarskich; 1996

3. Ancient Greek Medicine (online) [https://www.ancient.eu/Greek_M, downloaded: 23.06.2020].

4. Jonak A, Skrzek A. Krioterapia w odnowie biologicznej sportowców przegląd badań. Acta Bio-Opt Inform Med. 2009;15(4):321-319.

5. Magiera L, Walaszek R. Masaż sportowy z elementami odnowy biologicznej. Kraków: Biosport; 2008.

6. Kwolek A. Rehabilitacja medyczna. vol. I. Wrocław: Wydawnictwo Medyczne Urban \& Partner; 2003.

7. Mika T, Kasprzak W. Fizykoterapia. Warszawa: Wydawnictwo Lekarskie PZWL; 2003.

8. Skalska-Izdebska R, Kuzianm D, Pałka T, et al. Wykorzystanie fizjoterapii w odnowie biologicznej sportowców. Young sport science of Ukraine. 2012;3:195-204.

9. Pawelec R, Szczuka E, Kochański M. Hydroterapia w procesie szkolenia sportowego. Medicina Sportiva. 2007;8(4):104-106

10. Kasprzak WP, Mańkowska A. Fizykoterapia, medycyna uzdrowiskowa i SPA. Warszawa: Wydawnictwo Lekarskie PZWL, 2008.

11. Bauer A, Wicheć M. Przewodnik metodyczny po wybranych zabiegach fizykalnych. Ostrowiec Świętokrzyski: Markmed Rehabilitacja, 2008.

12. Straburzyńska-Lupa A, Straburzyński G. Fizjoterapia. Warszawa: Wydawnictwo Lekarskie PZWL; 2007.

13. Sieroń A, Cieślar G. Zastosowanie zimna w medycynie - kriochirurgia i krioterapia. Biała: Alfa Medica Press, 2003

14. Zagrobelny Z. Krioterapia miejscowa i ogólnoustrojowa. Wrocław: Wydawnictwo Medyczne Urban \& Partner, 2003

15. Gawroński W. Zimno (kriostymulacja a schładzanie) w leczeniu urazowych uszkodzeń narządu ruchu u sportowców. Chirurgia kolana, artroskopia, traumatologia sportowa 2005;2(2):59-69.

16. Kiwerski J. Rehabilitacja medyczna. Warszawa:Wydawnictwo Lekarskie PZWL; 2005.

17. Nowotny J. Podstawy fizjoterapii. p. II. Kraków: Wydawnictwo Kasper; 2004.

18. Szczuc M. Fale uderzeniowe w sporcie wyczynowym. Reh Prakt. 2008:4:32-33.

19. Stokłosa K. Fala uderzeniowa - podstawy teoretyczne i zastosowanie kliniczne. Rehabilitacja w praktyce. 2009;1:35-37 
20. Hołubowicz D. Terapia falą uderzeniową. Reh Prakt. 2008;3:26-27.

21. Janczak Z, Niemierzycka A, Zdrodowska A. Wpływ magnetoterapii i magnetostymulacji na proces restytucji powysiłkowej. Fizjoter Pol. 2002;2(3): 194-198.

22. Sieroń A, Pasek J. Pole magnetyczne, fizykoterapia w praktyce. Katowice: Elamed; 2014.

23. Magiera A. et al. Zmiany w układzie krążenia i oddychania zachodzące pod wpływem magnetostymulacji. Fizjoter Pol. 2004;4(4):316-322.

24. Woldańska-Okońska M, Czernicki J, Karasek M. The influence of lowfrequency magnetic fields of different parameters on secretion of cortisol in men. J Occupat Med Environment Health. 2013;26(1):92-101.

25. Kahn J. Elektroterapia. Zasady izastosowanie. Warszawa:Wydawnictwo Lekarskie PZWL; 2001.

26. Jaśkiewicz J, Bromboszcz J, Włoch T, Piekarz A, Blachuna L. Jonoforeza i fonoforeza. Podstawy teoretyczne i zastosowanie praktyczne. Reh Med. 2000;4(5):18-21

27. Kochański JW, Kochański M. Medycyna fizykalna. Gliwice: PHU Technomex; 2009.

28. Szczepanowska-Wołowiec B, Dudek J. Ocena skuteczności terapii prądami Traberta w dolegliwościach bólowych odcinka lędźwiowego. Stud Med. 2008;9:41-50.

29. Pyszora A, Kujawa J. Zastosowanie elektroterapii w leczeniu bólu. Pol Med Paliat. 2003;3:167-173.

30. Monopolar capacitive/resistive radio-frequency $448 \mathrm{kHz}$ (INDIBA active Therapy), working as a Rehabilitation Therapy in sports medicine. Retrospective analysis of its application in sports high Performance Center (CAR Sant cagat, Barcelona) during the period 2009-2011. Spain: Congress of AEMB; 20-23 June 2012
31. Ponikowska I, Kochański JW. Wielka księga balneologii i medycyny fizykalnej. vol.1. Aluna; 2017.

32. Ponikowska I. Wielka księga balneologii i medycyny fizykalnej. vol.2. Aluna; 2018.

33. Ponikowska I. Encyklopedia balneologii i medycyny fizykalnej. Aluna; 2015.

\section{ORCID and contributionship}

Justyna Laskowska - 0000-0002-5264-257X A-B, D, F Marta Woldańska-Okońska - 0000-0003-2884-2229 D-F

Olga Hadław-Klimaszewska - 0000-0002-5807-8850 D

Agnieszka Jankowska - 0000-0003-3758-7100 D

Adam Zdziechowski - 0000-0002-0446-2603 D

\section{Conflict of interest}

The Authors declare no conflict of intererest.

\section{CORRESPONDING AUTHOR} Justyna Laskowska

Departament of Rehabilitation and Physical Medicine, Medical University of Lodz

Hallera 1, 90-647, Łódź, Poland

e-mail:jus.czyzak@gmail.com

Received: 05.10 .2020

Accepted: 29.01.2021 